\title{
Effects of Training on the Performance of Senior Administrative Staff of University of Cape Coast
}

\author{
Raphael Papa Kweku Andoh (Corresponding author) \\ College of Distance Education, University of Cape Coast, Cape Coast, Ghana \\ E-mail: palphand@gmail.com
}

Robert Appiah

College of Distance Education, University of Cape Coast, Cape Coast, Ghana

E-mail: rappiah@ucc.edu.gh

Mark Kofi Adom-Nyankey

Oguaa Hall Administration, University of Cape Coast, Cape Coast, Ghana

E-mail: adomnyank@gmail.com

Received: May 24, 2016 Accepted: June 15, 2016 Published: June 26, 2016

doi:10.5296/bms.v7i1.9510 URL: http://dx.doi.org/10.5296/bms.v7i1.9510

\begin{abstract}
The purpose of the study was to investigate the effect of training programmes and opportunities for transfer of training on the performance of senior administrative staff of UCC. The descriptive survey design was employed for the study. The survey employed purposive and simple random sampling techniques in selecting a total of 158 respondents (senior administrative staff) for the study. The study revealed among others that training programmes are not administered regularly, perceptions/views of senior administrative staff about training programmes were not evaluated and their skills as well as behaviours were not assessed after training, there was inadequate practice during training and knowledge of staff were not measured after the training, the university does not place much emphasis on the application of training on the job and as well portals were not available to help store and
\end{abstract}




\section{Macrothink}

Business Management and Strategy

ISSN 2157-6068

2016, Vol. 7, No. 1

share information with staff. The following recommendations were made; There should be regular training programmes for the senior administrative staff of UCC, more time should be allotted for practice during training, measures should be put in place by the university management to ensure that there is much emphasis on the application of knowledge acquired from training programmes, the perceptions/views of senior administrative staff about training programmes should be evaluated, skills and behaviour of senior administrative staff should be assessed/evaluated after training, an informational maps should be developed and published to be used by staff.

Keywords: Training, Learning, Competence, Performance 


\section{Introduction}

For any enterprise to function effectively, it must have money, materials, supplies, equipment, and ideas about the services or products to offer those who may use its output and finally people, which is the human resource to run the enterprise (Sultana, Irum, Ahmed, \& Mehmood, 2012). Of all the above resources, human resources are the most valuable; with the machines, materials and the money, absolutely nothing gets done without employees (Shaheen, Naqvi \& Khan, 2013).

Boadu, Dwomo-Fokuo, Boakye, and Kwaning (2014) shared in the above when they indicated organisations are made by people and not buildings, equipment and brand names. Similarly, Hamid and Waheed (2011) and Sultana et al. (2012) highlight the importance of people in organisations when they asserted that the success and failure of every organisation is heavily dependent upon the performance of its employees (human resources). This further enforces the critical nature of employees for organisations. From the perspective of Sultana et al. (2012), one area of the Human Resource Management (HRM) function of utmost relevance to the effective use of human resources is training. They added that few people would argue against the significance of training as a major influence on the success of an organisation.

Following from the above, organisations have begun to realise that it is not adequate to leave everything to chance and natural selection and trial and error, hence the proliferation of graining and development programmes in organisations (Ongori \& Nzonzo, 2011). Thakore (2013), obviously affirms that training has considerably widened in the last few years.

Industrial report by the American Society for Training and Development, US organisations alone spend more than $\$ 126$ billion annually on employee training and development (Paradise, 2007). In Ghana, the training budget of organisations is ever increasing. For instance, according to Sarbeng (2013, p.161), “in 2010/2011, the University (of Cape Coast) spent an amount of $\mathrm{GH} \notin 200,000.00$ and $\mathrm{GH} ф 450,000.00$ on staff training and Faculty development respectively. In 2011/2012, GHф400,000.00 and $\mathrm{GH} \phi 700,000.00$ were also spent on staff training and Faculty development respectively". These investments are largely made on the basis that the University will gain competitive edge when it comes to staff output.

\subsection{Problem Statement}

Staff training and development are critical to the success of any organization. In recognition of the critical role of staff training on job output, most organization including higher educational institutions have put in strategies to implement for their staff. In the University of Cape Coast, there is a budgetary allocation for staff training and development programme every year. These programmes take the form of off-the-job and on-the-job training activities. The essence of these training activities are to improve employees work output. The senior administrative staff is one category of employees of the University of Cape Coast that has benefited from training programmes organised by the University. However, little appears to 
be known about the extent these training programes translate into actual work output of staff of the university. The crux of the study therefore, was to explore the effects of staff training programmes on work output among senior administrative staff of the University of Cape Coast, Ghana.

\subsection{Objectives of the Study}

The specific objectives of the study were to;

i. Examine the organisation of training programmes.

ii. Determine whether there are opportunities for the transfer of training.

iii. Determine if training have effect on employee performance.

\section{Literature Review}

\subsection{Overview of Training}

Training is considered as the means of upgrading or developing the knowledge, skills and behaviours of employees to enhance their effective and efficient functioning on their job. Monappa and Saiyadain (2008), think of training as the teaching or learning activities carried on for the primary purpose of helping members of an organisation to acquire and apply knowledge, skills, abilities, and attitudes needed by that organisation. Ivancevich (2010) also sees training as an attempt to improve current or future performance of an employee.

Following from the foregoing, training can be said to be an organised activity for increasing the knowledge, skills and attitudes of employees; reducing the gap between the actual performance and expected performance. It is usually a systematic procedure for helping employees to carry out specific jobs with proficiency. The purpose of training therefore is to achieve positive changes in terms of knowledge, skills and attitudes of employees with the view to bringing about improvement in their performance and that of the organisation as a whole.

Sherman, Baggland and Steven (1996) expressly indicated that the success of a training programme depends more on the organisation's ability to identify training needs so that if trainees are unable to learn what they are to learn, then training has been unsuccessful. They further add that if trainees are unable to learn, it is probable that some of the important learning principles had been overlooked.

The implication of what they are saying is that the success or otherwise of a training programme is frequently related to the recognition and application of basic principles of learning. This assertion is not necessarily right. If trainees are unable to exhibit what is expected of them, it could also mean that even though the organisation might have done all that is necessary to ensure a successful training programme, one or more of the external variables was absent. The external variables include person characteristics, climate for transfer and nature of the organisational environment. It could also mean that the problem cannot and should not be fixed by training. 


\subsection{Employee Performance}

Byars and Rue (1994) are of the view that performance is the degree of accomplishment of the tasks that make up an employee's job. On his part, Cooke (2000) explained performance as the achievement of specific tasks measured against predetermined or identified standards of accuracy, completeness, cost and speed. Efficiency, effectiveness, profitability and quality are measures considered when measuring performance (Ahuja, 1992).

The above, suggests that performance is subjective. The implication is that there are general expectations of employees in relation to their performance in every organisation. Employees can be said to have performed well when they have met expectations or performed up to standard. Performance is dependent on several factors such as effort, ability, motivation and attitude among others.

\subsection{External Factors That Influence Training and Performance Improvement}

The external factors that influence training and performance improvement are those factors that are outside the training programme yet without them training will not be beneficial to both the employees and the organisation in terms of performance improvement. They include person characteristics, climate for transfer and nature of organisational environment.

\subsubsection{Person Characteristics}

This refers to the employees' knowledge, skill, ability and attitude as measured against their readiness for training. Readiness for training implies whether employees have the ability, attitudes, beliefs and motivation required to learn the programme content and apply it on the job.

Motivation to learn; refers to trainees' desire to learn the content of the training programme. Employees may not have problem understanding and comprehending the programme but their attitudes and perception may inhibit learning Noe (as cited in Noe, 2010). Noe and Schmitt as cited in Noe (2010) are of the view that for trainees to be motivated to learn, they must be aware of their skill strength and weakness and of their link between the training programme and improvement of their weakness. The awareness can come from managers, team leaders or supervisors by sharing performance feedback with employees, holding career development discussions or making employees do a self-evaluation of their skill strengths and weakness as well as career interests and goals.

Basic skills; these are the basic skill set required of employees to successfully perform on the job and learn the content of the training programme. Basic skills include cognitive ability and reading ability. The possession of a high school diploma or a college degree according to Noe (2010) is no guarantee to employee having the necessary basic skills. To determine employee basic skill, literacy audit can be done.

Self-efficacy; is employees belief and confidence that they can successfully perform their job and learn the content of the training programme. Conditions which may inhibit employees' 
self-efficacy include those who have not been successful performers, not received training/formal education in a length of time, lack education or are inexperienced in the subject matter of the training programme (Noe, 2010).

\subsubsection{Climate for Transfer}

Climate for transfer has to do with the trainees' perceptions about characteristics of the work environment that facilitate or inhibit the use of trained skills or behaviours. Tracey, Tannenbaum and Kavanaugh as cited in Noe (2010) identify these as manager and peer support, opportunity to use skills and consequences of using learned capabilities.

Manager support; deals with the extent to which trainees' managers emphasize the importance of participating in training programmes and stress the application of the acquired skills on the job. This can be done by communicating expectations to trainees as well as providing the encouragement and resources needed to apply training on the job (Noe, 2010). More so, effective managers will regard post-training coaching as an integral part of their job. To improve learning transfer, managers can use "start to do", "continue to do", "do less", or "stop doing" when communicating Martin (as cited in Noe, 2010).

Peer support; a group of two or more trainees could also agree to meet either face to face or communicate by way of ICT to discuss their progress in using learned capabilities on their jobs. This may greatly ensure the transfer of training especially where there is the feeling of weak management support. Trainees may share experiences in applying training content on the job like how they cope with an environment/situation that interferes in the use of training content or how they obtain resources needed for the application of training content (Noe, 2010).

Opportunity to perform; this implies the extent to which trainees are provided with or actively seek experiences that allow for the application of newly acquired knowledge, skills and behaviours from the training programme. Opportunity to perform is influenced by both the work environment and trainee motivation. That is, trainees being given an opportunity to use learned capabilities by way of assignments from their managers and taking personal responsibility to actively seek assignments that allow them use newly acquired capabilities (Noe, 2010).

\subsubsection{Organisational Environment}

The climate for transfer is dependent on the organisational environment largely because for trainees to have the opportunity to perform and have peer and managerial support, the organisation must be a learning one and also concerned with knowledge management.

Learning organisation; is an organisation committed to learning, adaptation and change. In such an organisation, training is seen as part of a system designed to create human capital. Thus, training processes are carefully scrutinised and aligned with the organisation's goals. To become a successful learning organisation, the organisation may be required not only to place greater emphasis on training, but also change HRM systems to support learning (Noe, 


\section{Macrothink}

2010). Garvin, Edmondson and Gino (2008) assert that supportive learning environment, having processes and practices, and managers reinforcing learning are key features of a learning organisation.

Knowledge management; DeLong and Fahey (2000), think of knowledge management as the process of enhancing organisational performance by designing and implementing tools, processes, systems, structures and cultures to improve the creation, sharing and use of knowledge.

\section{Conceptual Framework}

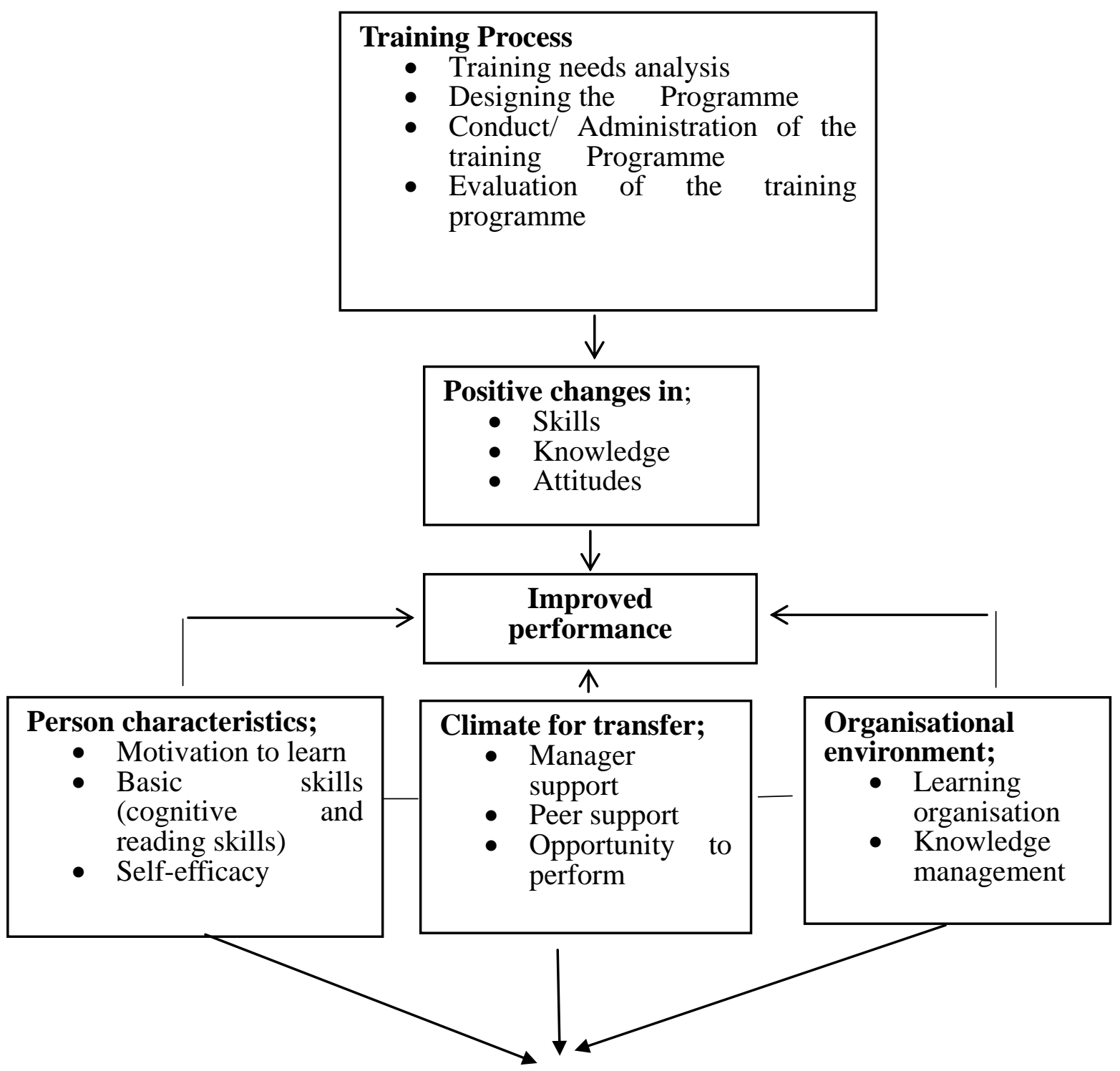

External factors that influence training and performance improvement

Figure 1. Improving performance using training.

Source: Authors' construct

The conceptual framework proposes that for employees to improve their performance, they 
must experience positive changes in their skills, knowledge and attitudes. This results from having an effective training programe guided by the training process.

Improving employee performance however, does not solely rely on the training or instructional programme regardless of how effective it is. There are other external factors (variables) responsible for performance improvement. They include trainees having the motivation to learn, basic skills required to learn, self-efficacy, support from managers and peers, opportunity to use acquired knowledge and skills as well as their organisation placing emphasis on knowledge management.

\section{Methodology}

\subsection{Research Design}

The study employed descriptive research design. Babbie (1999) recommends that design for the purpose of generalising from a sample to a population so that inferences can be made about the characteristics, attributes or behaviour of the population. Fraenkel and Wallen (1993) also indicate that it produces a good number of responses from numerous people at a time, provides a meaningful picture of events and seeks to explain people's perceptions and behaviours on the basis of information obtained at a point.

\subsection{Sample and Sampling Procedure}

A sample of 210 was selected from a population of 458 using Krejcie and Morgan's (1970) table for determining sample size from a given population. Purposive sampling was used to select the five colleges in UCC. The questionnaires were then administered to all senior administrative staff in the five colleges.

\subsection{Research Instrument}

The data collection instrument used in the study was a structured questionnaire. It had two parts; background information of respondents and statements with a five-point Likert scale; strongly disagree, disagree, neither agree nor disagree, agree and strongly agree.

\subsection{Reliability of Instrument}

The reliability of the instrument was estimated on scale items with the help of Statistical Package for Service Solution (SPSS). Using the SPSS, Cronbach's Alpha reliability statistics for the various part of the questionnaire were computed as $0.812,0.761$ and 0.906 . The total Cronbach's Alpha reliability statistics was computed as 0.899. According to Sekaran (2000), Cronbach's Alpha value less than 0.70 is considered to be poor, but above it is good and acceptable.

Table 1. Cronbach's Alpha

\begin{tabular}{|l|l|l|}
\hline Items & Cronbach's Alpha & Number of items \\
\hline
\end{tabular}




\begin{tabular}{|l|l|l|}
\hline Training programmes & 0.812 & 12 \\
\hline Opportunities for transfer of training & 0.761 & 8 \\
\hline Effect of training on performance & 0.906 & 9 \\
\hline Overall & 0.899 & 29 \\
\hline
\end{tabular}

\section{Data Analysis}

The response rate of the study was $75.24 \%$. The analysis of the questionnaire was done using the SPSS. The data collected were summarised and analysed using simple frequencies, mean, standard deviation, t-test and regression analysis to assess the effects of training on performance. The determination of categories of perceived satisfaction was based on Kubiszyn and Bonich's (1984) assertion that higher weights are associated with positive attitudes and lower weights with negative attitudes and as a rule, a mean rating of 3.0 is used, that is, if the score is greater than 3.0, a positive attitude exists and if the score is less than 3.0, then a negative exists.

\subsection{Organisation of Training Programmes}

From table 2, on the statement about the fact that there exist a documented human resource training programmes in the university, it was revealed that there was a mean value of 3.23 and a standard deviation of 1.09. This implies that majority of the senior administrative staff agreed on their responses to the statement and their responses differ much from each other concerning the statement. On the second statement, the results showed that majority of the respondents agreed on their responses to the organization and systematic planning of the training programmes and their responses differ much from each other concerning the statement. This is evident from the computed mean and standard deviation values of 3.20 and 1.05 respectively. Following their responses on the regular administration of the training programmes, the results showed a mean of 2.77 and s standard deviation value of 1.08. This implies that majority of the respondents disagreed and their responses differ much from each other.

In relation to the training programmes taking into consideration the needs of the senior administrative staff, the results showed that there was a mean of 3.02 and a standard deviation value of 1.05 . This gives the implication that majority of the respondents were uncertain on the statement and their responses differ much from each other. Owing to the results on the statement that training programmes take into consideration the needs of the department/unit/college, it was shown that majority of the respondent were uncertain and their responses differ much from each other $(\mathrm{M}=3.09, \mathrm{SD}=1.02)$. The results also revealed that training was relevant to the job schedules of the respondents and their responses differ much from each other $(\mathrm{M}=3.61, \mathrm{SD}=0.98)$.

Additionally, on the responses of the senior administrative staff as to whether or not the objectives of the training programmes were stated before the training began, it was found that 
there was a computed mean of 3.47 and a standard deviation value of 1.73 , which gives the indication that majority of the respondent agreed on the statement and their responses differ much from each other. Furthermore, in an attempt to solicit from the respondent on the comfortability of the training environment, it was realized that the mean value was 3.41 and the standard deviation value was 0.98 . This follows logically that majority of the respondents agreed with the statement and their responses did not differ much from each other. Moreover, when they were asked to indicate whether or not there was enough practice during training, the results showed a mean value of 2.72 and a standard deviation of 1.08 . This gives the implication that majority of the respondents disagreed on the statement and their responses differ much from each other.

Table 2. The organisation of Training Programmes

\begin{tabular}{|l|l|l|}
\hline Statements & Mean & $\begin{array}{l}\text { Std. } \\
\text { Deviation }\end{array}$ \\
\hline $\begin{array}{l}\text { The University has a documented human resource training } \\
\text { programmes }\end{array}$ & 3.23 & 1.085 \\
\hline Training programmes are organised and planned systematically & 3.20 & 1.057 \\
\hline Training programmes are administered regularly & 2.77 & 1.078 \\
\hline Training programmes take into consideration my needs & 3.02 & 1.049 \\
\hline $\begin{array}{l}\text { Training programmes take into consideration needs of my } \\
\text { department/unit/college }\end{array}$ & 3.09 & 1.018 \\
\hline Training is relevant to my job schedules & 3.61 & 0.983 \\
\hline $\begin{array}{l}\text { Objectives of training programmes are stated before training } \\
\text { starts }\end{array}$ & 3.47 & 1.734 \\
\hline Training environment is comfortable & 3.41 & 0.980 \\
\hline There is enough practice during training & 2.72 & 1.079 \\
\hline My knowledge after training is measured & 2.84 & 1.093 \\
\hline My perceptions/view of the training programme is evaluated & 2.84 & 1.056 \\
\hline My skills and behaviour are assessed after training & 2.77 & 1.058 \\
\hline Overall & 1.45 & 1.412 \\
\hline
\end{tabular}

Source: Field Data, 2015.

Paying attention to the responses of the senior administrative staff on evaluation, the results discovered that knowledge of the senior administrative staff were not measured and their responses did differ much concerning the statement. This can be deduced from the mean and standard deviation values of 2.84 and 1.09 respectively. Another indicator to solicit the responses of the respondents on evaluation was the evaluation of their perception or views of the training programme. On the basis of that the results showed a mean value of 2.84 with a standard deviation value of 1.06. This implies mathematically that majority of the respondents disagreed with the statement and their responses differ much from each other 
concerning the statement. The last indicator as far as the organisation of training programmes in terms of evaluation; seeking the extent to which they agreed or disagreed on the statement that their skills and behaviours are assessed after the training. With reference to that it was known from the results that a mean value of 2.77 and a standard deviation of 1.06 were found. This gives the implication that majority of the respondents disagreed and their responses differ much from each other. The overall mean and standard deviation values of the responses of senior administrative staff on the organisation of training programmes in the University of Cape Coast rated 1.45 and 1.41 respectively. This gives reason to the fact that majority of the respondents strongly disagreed with the statements that sought to solicit their responses on the organisation of training programmes and their responses differ much from each other concerning the statements

\subsection{Opportunities for the Transfer of Training}

From the first statement in Table 3, majority of the respondents agreed that their department/unit or immediate head encourages them to attend training programmes. Their responses differ much from each other at a mean value of 3.50 and a standard deviation value of 1.16. On the second statement, the result found out that there was a computed mean value of 3.68 and a standard deviation of 3.71. This implies that majority of the senior administrative staff strongly agreed that head of department/unit or immediate head encourages them to apply skills and knowledge acquired from training programmes and their responses differ much from each other. Regarding their responses on the statement that colleagues share their progress on using learned capabilities on their job, a mean of 3.22 and a standard deviation of 1.73 were established. It can be deduced from the results that majority of the respondents agreed and there were differences in their responses.

In the same angle respondents were asked to show the extent to which they agreed or disagreed with the statement that they are given tasks that allow them to apply knowledge and skills acquired. The results revealed that majority of the senior administrative staff agreed with the statement and there were much differences in their responses concerning the statement. This is evident from the computed mean and standard deviation values of 3.20 and 1.02 respectively.

Another indicator that was used to find out whether or not the senior administrative staff were given opportunities to transfer the knowledge and skills acquired from training during work was on the statement that the university places much emphasis on the application of training on the job. Paying attention to the results on the issue under discussion, it was indicated that a mean value of 2.94 and a standard deviation value of 1.12 were computed. This implies that majority of the respondents disagreed on the statement and their responses differed much from each other. Additionally, the respondents agreed on the statement that training programmes are in line with the university's vision, mission and goals and their responses differ much from each other $(\mathrm{M}=3.56, \mathrm{SD}=1.01)$.

A closer look at the results also brings to life that majority of the senior administrative staff 
disagreed that portals were available to help store and share information with staff and there were much variations in their responses $(M=2.98, S D=2.61)$. Finally, it was shown from the results that on the majority response, there are no maps that identify where specific knowledge is stored and the responses of the respondents differ much from each other concerning the statement. The overall mean and standard deviation values for the responses of the senior administrative staff on the provision of opportunities for the transfer of knowledge and skills acquired from training during work rated 0.95 and 1.39 respectively. This gives the mathematical implication that majority of the respondents strongly disagreed on the statement that pursued their responses on the provision of opportunities for the transfer of knowledge and skills acquired from training during work and their responses differ much from each other concerning the statements.

Table 3. Opportunities for the Transfer of training

\begin{tabular}{|l|l|l|}
\hline Statement & Mean & Std. Deviation \\
\hline $\begin{array}{l}\text { My head of department/unit or immediate head encourages } \\
\text { me to attend training programmes }\end{array}$ & 3.50 & 1.161 \\
\hline $\begin{array}{l}\text { My head of department/unit or immediate head encourages } \\
\text { me to apply skills and knowledge acquired from training } \\
\text { programmes }\end{array}$ & 3.68 & 3.713 \\
\hline $\begin{array}{l}\text { Colleagues share their progress on using learned } \\
\text { capabilities on their job }\end{array}$ & 3.22 & 1.738 \\
\hline $\begin{array}{l}\text { I am given tasks that allow me apply knowledge and skills } \\
\text { acquired }\end{array}$ & 3.20 & 1.019 \\
\hline $\begin{array}{l}\text { The university places much emphasis on the application of } \\
\text { training on the job }\end{array}$ & 2.94 & 1.116 \\
\hline $\begin{array}{l}\text { Training programmes are in line with the university's } \\
\text { vision, mission and goals }\end{array}$ & 3.56 & 1.013 \\
\hline $\begin{array}{l}\text { Portals are available to help store and share information } \\
\text { with staff }\end{array}$ & 2.98 & 2.605 \\
\hline $\begin{array}{l}\text { There are informational maps that identify where specific } \\
\text { knowledge is stored }\end{array}$ & 2.55 & 1.050 \\
\hline Overall & 0.95 & 1.391 \\
\hline
\end{tabular}

Source: Field Data, 2015.

\subsection{Effects of Training on Performance}

Table 4 shows the effect of training programmes on the performance of Senior Administrative Staff. The results showed that the t-value for the statement on the ability of the respondents to meet departmental/organizational goals/objectives after training was 0.82 and the computed regression coefficient value was 0.45 . This implies that the ability of senior administrative staff to meet departmental/organizational goals/objectives after training contributed to $45 \%$ of their performance. 
Paying attention to the second statement, it was revealed that the $t$-value was 0.36 and the regression coefficient value was 0.72 . This follows logically that training programmes and opportunities for transfer of training contributed to $72 \%$ of the performance of the senior administrative staff in making less mistakes after the training. This presupposes that the degree of making mistakes by senior administrative staff of the university in carrying out duties is reduced drastically. Following their responses on the level of confidence in carrying out duties after the training, it was indicated that the t-value was 0.13 and the regression coefficient value was 0.90 . This gives the implication that training programmes and opportunities for transfer contributed to $90 \%$ of their confidence level as far as their performances are concerned.

Table 4. Extract of Regression Analysis for the Effects of Training Programmes on Employee Performance

\begin{tabular}{|l|l|l|}
\hline Statement & T-value & $\begin{array}{l}\text { Regression } \\
\text { Coefficient } \\
\text { (Sig. 2-tailed) }\end{array}$ \\
\hline $\begin{array}{l}\text { I am able to meet departmental/organisational } \\
\text { goals/objectives after training }\end{array}$ & 0.82 & 0.45 \\
\hline $\begin{array}{l}\text { I make less mistakes in carrying out my duties after } \\
\text { training }\end{array}$ & 0.36 & 0.72 \\
\hline $\begin{array}{l}\text { I become confident in carrying out my duties after } \\
\text { training }\end{array}$ & 0.13 & 0.90 \\
\hline I am motivated to carry out my duties & 1.50 & 0.14 \\
\hline My job satisfaction level increases & 0.96 & 0.34 \\
\hline $\begin{array}{l}\text { I am equipped with the right information, } \\
\text { knowledge and skills after training }\end{array}$ & 0.62 & 0.56 \\
\hline I become more effective in solving problems & 0.08 & 0.94 \\
\hline $\begin{array}{l}\text { My strategic knowledge is enhanced (I know when } \\
\text { to apply a specific knowledge/skill) }\end{array}$ & 0.10 & 0.93 \\
\hline I become more creative and innovative after training & 1.37 & 0.74 \\
\hline
\end{tabular}

Source: Field Data, 2015.

Additionally, it was rendered on the statement that sought to find out their motivation to carry out duties that there was a t-value of 1.50 and regression coefficient value of 0.14 . This makes it clear that training programmes and opportunities for transfer of training contribute to $14 \%$ of the motivation of the senior administrative staff to carry out their duties. Again it was found that the t-value and the regression coefficient value for increase in the level of job satisfaction were 0.96 and 0.34 respectively. This means that the effect of training programmes contributed to $34 \%$ of the job satisfaction levels of the senior administrative staff. It was then revealed from the results that on equipping the respondents with the right information, knowledge and skills after training, the computed t-value and regression 
coefficient values were 0.62 and 0.56 respectively. This brings to light that being equipped with the right information, knowledge and skills after training contributed to more than $50 \%$ of the performance of the employees.

The next item for discussion was on the effectiveness of the respondents in solving problems. On the basis of that the results showed a t-value of 0.08 and regression coefficient value of 0.94. This gives reason to the fact that the training programmes contributed to $94 \%$ of the performance of the employees. A closer look at the results also specified that it enhances the strategic knowledge ability of the employees at a percentage of 93. This is apparent when the t-value was 0.10 and the computed regression coefficient value was 0.93 . Finally, it becomes clear that training programmes enhanced the creative ability of the employees. This is shown from the values of the ' $t$ ' and regression coefficient at 1.37 and 0.74 respectively.

\section{Key Findings}

The following were the key findings from the study;

1. On the organisation of training programmes, the senior administrative staff reported that University of Cape Coast has a documented human resource training programmes.

2. The study found out that training programmes are organised and planned systematically.

3. With regards to administration of training programmes, it emerged that training programmes were not administered regularly.

4. With respect to evaluation, the study found out that training programmes were relevant to the job schedules, objectives were stated before training starts and the training environment were comfortable.

5. On the other hand, it was specified that there was inadequate practice during training and knowledge of the respondents were not measured after the training. This is as a result of inadequate practice during training.

6. Perceptions/views of senior administrative staff about training programmes were not evaluated and their skills as well as behaviour were not assessed after training

7. Senior administrative staff of UCC pointed out that they were encouraged by their head of department/unit or immediate supervisors to attend training programmes and to apply the skills and knowledge acquired from training programmes.

8. Additionally, it was reported that they were given tasks that gives them the opportunities to apply their knowledge and skills acquired and training programmes are in line with the university's vision, mission and goals.

9. Despite these opportunities, it was signposted that UCC does not place much emphasis on the application of training on the job and as well portals were not available to help store and share information with staff. 
10. There was lack of informational maps that identify where specific knowledge is stored.

11. The study further found that training programmes and opportunities for transfer of knowledge and skills contributed to $45 \%$ of the employee performance, it reduced mistakes by $72 \%$ and increased their confidence level at $90 \%$.

12. In spite of these good areas it emerged that their motivation to carry out duties and their job satisfaction levels were increased by $14 \%$ and $34 \%$ respectively.

13. The results again revealed that training employees equipped them with the right information by more than $50 \%$, increased their effectiveness in solving problems by $94 \%$, enhanced their strategic knowledge ability by $93 \%$ and also improved the creative and innovative ability of the senior administrative staff by $74 \%$.

\section{Conclusions}

The study concludes that training programmes in UCC are organized and planned systematically. In the same angle, the training programmes were not administered regularly. Additionally, there was inadequate practice during training and knowledge of staff were not measured after the training. It is also noteworthy to mention that perception/opinions of the training programme were not evaluated and skills as well as behaviour of the senior administrative staff were not assessed after the training.

On opportunities for the senior administrative staff to transfer knowledge and skills acquired from training unto work, the study concludes that the university gives tasks that offers them the opportunities to apply their knowledge and skills acquired and training programmes are in line with the university's vision, mission and goals. However, the university does not place much emphasis on the application of training on the job, much emphasis is not placed on the application of training on the job and as well portals were not available to help store and share information with staff.

Finally, the study concludes that training programmes and opportunities for transfer of knowledge and skills contributed to $45 \%$ of the employee performance, it reduced their ability to make mistakes by $72 \%$ and increased their confidence level at $90 \%$. Motivation to carry out duties and job satisfaction levels were increased by $14 \%$ and $34 \%$ respectively. The results also revealed that it increase their ability to be equipped with the right information by more than 50\%, increased their effectiveness in solving problems by $94 \%$, enhanced their strategic knowledge ability by $93 \%$ and also improved the creative and innovative ability of the senior administrative staff by $74 \%$.

\section{Recommendations}

The following recommendations are being made for consideration and implementation:

1. There should be regular training programmes for the senior administrative staff of UCC. When this is done staff will always remain productive. 
2. More time should be allotted for practice during training to help trainees master the required knowledge, skill or behaviour.

3. Measures should be put in place by the university management to ensure that there is much emphasis on the application of knowledge acquired from training programmes.

4. The perceptions/views of senior administrative staff about training programmes should be evaluated. This will help in collecting information about the training programme to guide decision making on its relevance and effectiveness.

5. Skills and behaviour of senior administrative staff should be assessed/evaluated after training. When this is done the planners of the training programmes would be able to identify strengths and weakness and make provisions for them.

6. Informational maps should be developed and published since this will direct staff to where specific knowledge they need to know and apply is stored and also make knowledge explicit.

7. Portals should be created and made available to help store and share information required for the execution of tasks with staff.

\section{References}

Ahuja, K. K. (1988). Advanced personal management. New Delhi: Kalyani Publishers.

Babbie, E. (1999). Practice of social research. New York: WadsworthPublishing Company.

Boadu, F., Dwomo-Fokuo, E., Boakye, J. K. \& Kwaning, C. O. (2014). Training and development: A tool for employee performance in the district assemblies in Ghana. International Journal of Education and Research, 2(5), 130-146. [Online] Available: http://www.ijern.com/journal/May-2014/42.pdf (November 3, 2015)

Byars, L. L., \& Rue, L. W. (1994). Human resource management. Boston: Irwin.

Cooke, J. (2000). International Human Resource Management: A cross cultural approach. London: Sage Publications Ltd.

DeLong, D. W., \& Fahey, L., (2000). Diagnosing cultural barriers to knowledge management. Academy of Management Executive, 14(4), 113-127. [Online] Available: http://www.smartworkforcestrategies.com/Portals/0/Published\%20Articles/DeLong-Diagnosi ngCulturalBarriersToKnowlMgt.pdf (August 2, 2015)

Fraenkel, J. R., \& Wallen, N. E., (1993). How to design and evaluate research in education. New York: McGraw-Hill Companies Inc.

Garvin, D. Edmondson, A., \& Gino, F. (2008). Is yours a learning organization?" Harvard Business Review. [Online] Available: http://provost.tufts.edu/celt/files/Is-Yours-a-Learning-Organization-by-Garvin-Edmondson-an d-Gino.pdf (August 15, 2015) 
Hamid, A., \& Waheed, A. (2011). Employee development and its effects on employee performance framework. International Journal of Business and Social Science, 2(13), 224-229.

Available:

http://www.ijbssnet.com/journals/Vol._2_No._13_Special_Issue_July_2011/26.pdf (August 2, 2015)

Ivancevich, J. M. (2010). Human resource management. Boston: Irwin McGraw-Hill.

Krejcie, R. V., \& Morgan, D. W. (1970). Determining sample size for research activities. London: George Allen and Unwind.

Kubiszyn, J., \& Bonich, K (1984). Human resource management and development: Current issues and Themes. London: MacMillan Press Ltd.

Monappa, A., \& Saiyadain, M. (2008). Personnel Management (2nd ed.). Tata New Delhi: McGraw-Hill.

Noe, R. A. (2010). Employee training and development (5thed.). New York: McGraw-Hill. [Online]

Available: http://202.74.245.22:8080/xmlui/bitstream/handle/123456789/435/Employee\%20Training\%2 0and\%20Development.pdf?sequence=1 (August 2, 2015)

Ongori, H., \& Nzonzo, C. (2011). Training and development practices in an organisation: An intervention to enhance organisational effectiveness. International Journal of Engineering and Management Services, 2(4), 187-198. [Online] Available: http://scienceandnature.org/IJEMS-Vol2(4)-Oct2011/IJEMS_V2(4)3.pdf (October 30, 2015)

Paradise, A. (2007). State of the Industry: ASTD's Annual Review of Trends in Workplace Learning and Performance. Alexandria; VA: ASTD

Sarbeng, I. B. (2013). Staff training and development interventions and teaching performance: Application of structural equation modelling. International Journal of Human Resource Studies, 3(4), 159-176. : http://dx.doi.org/10.5296/ijhrs.v3i4.4705

Sekaran, G. (2000). Research methodology and statistics techniques. London: Prentice Hall.

Shaheen, A., Naqvi, S. M. H., \& Khan, M. A. (2013). Employees training and organisational performance: Mediation by employees' performance. Interdisciplinary Journal of Contemporary Research in Business, 5(4), 130-149. [Online] Available: http://journal-archieves35.webs.com/490-503.pdf (October 29, 2015)

Sherman, J., Baggland, W., \& Steven, A (1996). Principles of human resource development. Massachusetts MA: Addison-Wesley Publishing Company Inc.

Sultana, A., Irum, S., Ahmed, K., \& Mehmood, N. (2012). Impact of training on employee performance: A study of telecommunication sector in Pakistan. Interdisciplinary Journal of Contemporary Research in Business, 4(6), 646-661. [Online] Available: http://journal-archieves24.webs.com/646-661.pdf (October 29, 2015) 


\section{Macrothink}

Business Management and Strategy ISSN 2157-6068

Thakore, D. (2013). Training- A strategic HRM function. International Journal of social and humanistic sciences, $11, \quad 84-90 . \quad$ [Online] Available: https://www.scipress.com/ILSHS.11.84.pdf (October 15, 2015)

\section{Copyright Disclaimer}

Copyright for this article is retained by the author(s), with first publication rights granted to the journal.

This is an open-access article distributed under the terms and conditions of the Creative Commons Attribution license (http://creativecommons.org/licenses/by/3.0/). 